\title{
References:
}

1. Ahmadi-Azad S. The effect of coded and uncoded written corrective feedback types on Iranian EFL learners' writing accuracy. Theory and Practice in Language Studies. 2014. Vol. 4(5). P. 1001-1007.

2. Brown D. The type and linguistic foci of oral corrective feedback in the L2 classroom: A meta-analysis. Language teaching research. 2016. Vol. 20(4). P. 436-458.

3. Hattie J., Timperley H. The power of feedback. Review of Educational Research. 2007. Vol. 77(1). P. 37-66.

4. Lyster R., Ranta L. Corrective feedback and learner uptake. Studies in Second Language Acquisition. 1997. Vol. 19. P. 37-66.

5. Shute V. J. Focus on formative feedback. Review of Educational Research, 2008. vol. 78(1). P. 153-189.

6. Värlander S. The role of students' emotions in formal feedback situations. Teaching in Higher Education. 2008. vol. 3(2). P. 145-156.

7. Yang M., Carless D. The feedback triangle and the enhancement of dialogic feedback processes. Teaching in Higher Education. 2013. Vol. 18(3). P. 285-297.

DOI https://doi.org/10.30525/978-9934-26-039-1-96

\section{SELF-OPTIMAZING LEARNING}

\author{
Laptinova Yu. I. \\ Candidate of Sciences in Philosophy, \\ Senior Teacher at the Department of Foreign Languages \\ Kharkiv National I. P. Kotlyarevsky University of Arts \\ Goncharova M. O. \\ Senior Teacher at the Department of Foreign Languages \\ Kharkiv National I. P. Kotlyarevsky University of Arts \\ Kharkiv, Ukraine
}

In recent years there has been a fundamental shift in language teaching, away from tenets of behaviorist psychology and structural linguistics and toward cognitive, and later, socio-cognitive psychology and more contextualized, meaning-based views of language [1]. This shift is generally known as the move from teacher-centered instruction to learner-centered or learningcentered instruction i.e. from the teacher to the student. Farrell and Jacobs list 
the key characteristics of this shift in their article «Paradigm Shift: Understanding and Implementing Change in Second Language Education»:

- focus on the learning process rather than on the products that learners produce (get a high score on an exam);

- focus on the social nature of learning rather than on students as separate, decontextualized individuals;

- focus on the process of learning rather than the subject matter;

- focus on the teachers as co-learners;

- focus on the outcome of the activity rather than on the language used to achieve that outcome;

- focus on the cooperative learning, and so on and so forth [2].

Since learning became a key subject in teaching, a lot of new educational approaches have appeared which aim to organize classroom activities into academic settings: Content and Language Integrated Learning, Cooperative Language Learning, Computer Assisted Language Learning, Mobile Assisted Language Learning, Phenomenon-Based Learning, Inquiry-Based Learning, Project-Based Learning, Peer-To-Peer Learning, School-To-School ELearning, and on and on-the possibilities are endless. All these StudentCentered Instructions focus on skills and practices that enable successful learning. Each of them is good in its own way. Definitely no approach can fully satisfy every student. Each learning might be affected by disturbances or have much uncertainty and uncontrollable disorder, so that it is impossible to make method suitable to all learners in online/offline classes. Moreover, learning is not fixed or static, but is continually developing and growing. So, the concept of learning styles has been the subject of considerable debate and criticism. A huge number of researchers and practitioners are trying to figure out what makes learning a good learning. Terry Heick, the founder and director of TeachThought, lists 10 characteristics of a highly effective learning environment [3]. Dr. Tony Bates, the author of eleven books in the field of online learning and distance education, offers his way to build an effective learning environment [4]. At the very end of his article, he asks a question «What other components would you add to a successful learning environment?»

In this paper, we propose another component which is crucial to having a high quality of learning. It is a self-optimization mechanism, which makes the best or most effective use of a learning process by handling complexity and unforeseen disturbances within learning. In other words, it's a self-regulating and self-adjusting process, capable of monitoring itself and modifying itself in order to achieve objectives. 
We believe that the best learning is one in which learners take full accountability for himself and his actions, doing the diagnosing, the goalsetting, and the planning; resolving their problems or reactions to disturbances. Those who are unable to adjust well are more likely to have anxiety or fatigue, as well as experience feelings of hopelessness, failure, difficulty concentrating etc. In order to develop a self-optimization mechanism every learner should

- evaluate progress;

- do the diagnosing;

- remedy the problem;

- adequately respond to disturbances;

- adjust to circumstances;

- make compromises;

- prioritize;

- have a realistic perception;

- select a best learning from some set of available alternatives;

- deal with emerging opportunities;

- capitalize on strengths;

- acknowledge weaknesses;

- establish cooperation as a value;

- minimize time and effort wastage.

The above self-optimization strategies are of high significance for learning. Implementing them will take a much practice and preparation, but will pay dividends in the classroom.

We conclude that teaching for the future must focus on cultivating selfoptimizing learning. In our approach, self-optimizing learning relates to the learning process by which learners are capable to manage their own study by detecting disturbances, exploring opportunities, making a normal adjustment to some needs, varying requirements, obstacles in the learning environment.

\section{References:}

1. Thomas S. C. Farrell, George M. Jacobs. Essentials for Successful English Language Teaching. Continuum international publishing group ltd. 2010, $157 \mathrm{p}$.

2. George M Jacobs, Thomas S C Farrell. Paradigm Shift: Understanding and Implementing Change in Second Language Education. URL: http://www.zait.uni-bremen.de/wwwgast/tesl_ej/ej17/a1.html

3. Terry Heick. 10 Characteristics Of A Highly Effective Learning Environment. URL: https://www.teachthought.com/learning/10-characteristics-of-a-highly-effective-learning-environment/ 
4. Dr. Tony Bates. Building an effective learning environment. URL: https://www.tonybates.ca/2016/02/22/building-an-effective-learningenvironment/

DOI https://doi.org/10.30525/978-9934-26-039-1-97

\title{
INTERACTIVE TECHNOLOGIES IN FOREIGN LANGUAGE LESSONS AS A WAY OF CRITICAL THINKING FORMATION FOR STUDENTS OF NON-LINGUISTIC UNIVERSITIES
}

\author{
Nykyporets S. S. \\ Lecturer at the Department of Foreign Languages \\ Vinnytsia National Technical University \\ Vinnytsia, Ukraine
}

The modern world cannot be imagined without the World Wide Web, it is even more difficult to imagine a teenager who does not use social networks for daily communication. The huge popularity of social networks has created new opportunities for mastering foreign languages. Today, communication with native speakers, correspondence with peers from other countries, the creation and implementation of joint telecommunication projects, participation in text and voice chats, reading hypertext information in a specialty, using online dictionaries and much more has become an everyday reality. Advances in technology mean that language practice that fosters language acquisition, communication competence and motivation is available to learners. However, as a result of the rapid development of technology, a need arose for lifelong education: knowledge is aging so quickly that you have to constantly retrain. Learning is becoming one of the main skills. And it is this skill that is acquired when learning a foreign language using computer technology.

The development of critical thinking becomes very relevant in times of intense social change, when it is impossible to act without constant adaptation to new political, economic and other circumstances, without the effective solution of problems, substantial part of which is unpredictable. That is why the vital need for critical thinking for our Ukrainian educational system is obvious. Only in this way can we think about the development of democracy in accordance with the requirements of world society.

When using interactive methods in English classes, a number of problems arising among students can be noted: the inability to express their own opinions; fear of being mocked by other students; evaluate the opinions of 156 